\title{
Shortened of the crown and root lengths of the mandibular permanent molar in beta major thalassemia children
}

\author{
Indra Primathena*), Eriska Riyanti*, Ria Firman** \\ *Department of Pedodontics Faculty of Dentistry Universitas Padjadjaran, Bandung \\ **Department of Dentomaxillofacial Radiology Faculty of Dentistry Universitas Padjadjaran, \\ Bandung
}

\section{ABSTRACT}

Beta major thalassemia is a genetic inherited blood disorder due to a genetic mutation on the polypeptide chains of haemoglobin which is manifestated in the growth and development of the tooth. The objectives of the investigation was to obtain differences of the crown and root lengths of the mandibular first right side permanent molar between beta major thalassemia children and normal children group at the matching ages of 11 to 13 years old. The descriptive comparative method was used in the study and samples were selected using the purposive sampling technique. Sample numbers, which were obtained using the consecutive sampling technique, consists of 12 children of beta major thalassemia and 12 of normal children at the matching ages of 11 to 13 years. Periapical radiographs of both thalassemia and normal children were administered using the method of Seow and Lai. Data were analyzed using t-test method. The study revealed that the crown and root lengths of the mandibular first right side permanent molar of beta major thalassemia children was shorter than normal children at the ages of 11 to 13 years.

Key words: Beta major thalassemia, crown and root lengths of the mandibular first right side permanent molar, age

\section{ABSTRAK}

Thalassemia beta-mayor adalah kelainan darah herediter karena mutasi genetik pada rantai beta hemoglobin yang bermanifestasi pada tumbuh-kembang gigi. Tujuan penelitian ini untuk mendapatkan perbedaan panjang mahkota dan akar molar pertama bawah kanan tetap antara anak thalassemia betamayor dan anak normal usia 11-13 tahun. Penelitian dilakukan dengan metode deskriptif komparatif. Sampel dipilih melalui teknik purposive sampling. Jumlah sampel didapat 12 anak thalassemia betamayor dan 12 anak normal usia 11-13 tahun yang diambil dengan teknik consecutive sampling. Dilakukan pengukuran pada foto periapikal anak thalassemia beta-mayor dan anak normal dengan menggunakan metode Seow and Lai. Data dianalisis menggunakan uji-t. Kesimpulan hasil penelitian menunjukkan bahwa panjang mahkota dan akar molar pertama tetap bawah kanan anak thalassemia beta-mayor lebih pendek daripada anak normal usia 11-13 tahun.

Kata kunci: Thalassemia beta-mayor, panjang mahkota dan akar molar pertama bawah kanan tetap, usia

*)Correspondence author: Indra Primathena, Department of Pedodontic Faculty of Dentistry Universitas Padjadjaran

Jl. Sekeloa Selatan No. 1 Bandung, West Java-Indonesia, Tel./Fax: +6222-2504985/2532805 


\section{INTRODUCTION}

Thalassemia is a blood disorder that inherited genetically. This disorder characterized by the decreased of globulin protein chain production. It causes an anemia microcytic which grouped into alpha type and beta type. Based on their clinical and genetical orders, thalassemia can be grouped into two types the major type (homozygote) and the minor type (heterozygote). Beta major thalassemia or Cooley anemia is the worst haemolytic anemia. This condition occured as a result of beta chain hemoglobin produced abnormally. The symptoms generally occured at 4-6 months before birth while the shift from $\mathrm{HbA}$ to $\mathrm{HbF}$ occured. The patient commonly possessed a large number of hematocryte as much as $20 \%$ from normal. This condition developed oftenly as a complication from chronical anemia. One of those complication is delayed or retarded growth of the child. ${ }^{1}$

According to the Haematology and Oncology Department of Pediatric Department in FKUI (Faculty of Medicine, Universitas Indonesia) in 2002, as much as 2500 Indonesian children born with beta-major thalassemia in the respected year. Based on data of several large hospitals and educational center, Indonesia had a frequency of development of beta-major thalassemia 3-8\%.2

Children with beta-major thalassemia can not grew normally and had been retarded since newborn. ${ }^{3}$ One way to determine their retardation on the face and oral cavity is to observe the physical appearance and their dental radiograph examination. ${ }^{4}$ Radiograph study in Jordan ${ }^{10}$ suggested that children with beta-major thalassemia showed a larger maxilla, shorter teeth length, thinner lamina dura and also smaller upper maxillary sinus.

Growth variation is a variation of growth velocity in particular ages. Variation example is a puberty growth spurt. Tofani in Foster ${ }^{5}$ discovered that maximum puberty growth age was between 11-13 years old. In that range of ages the right lower permanent first molar had completed their phases of growth and development. According to Berkovitz et al. ${ }^{6}$ the lower permanent first molar enamel completion is between the age of 4 years old, eruption phase is between 6 to 7 years old, and completion of root anatomy is between 9 to 10 years old.

RSUP Dr. Hasan Sadikin Bandung (Dr. Hasan Sadikin Educational Hospital, Bandung) is a type of a educational hospital and had a role as the highest referral hospital in West Java. Around 400 patients with beta-major thalassemia registered in the Thalassemia Clinic of Pediatric Department of RSUP Dr. Hasan Sadikin Bandung by 2008, 212 patients were children and 62 of them were aged 11-13 years old.

Even though beta-major thalassemia is a genetically disorder disease with relatively high frequency and one of the most important issues of community health, nevertheless literature regarding the size of crown and root of beta-major thalassemia children had not much been studied in Indonesia.

The objectives of this study were to determine the differences of crown and root length of the right lower permanent first molar in beta major thalassemia children compared with the normal children aged at 11-13 years old in the Thalassemia Clinic of Pediatric Department in RSUP Dr. Hasan Sadikin Bandung.

\section{METHODS}

Subject of this study divided into two groups, one group of beta-major thalassemia children and the other group was normal children aged 11-13 years old in the Thalassemia Clinic of Pediatric Department, RSUP Dr. Hasan Sadikin Bandung. Periapical radiograph used in this study referred as a secondary data. This was a comparative descriptive study. Sampling technique used was the purposive sampling technique, while the smaple amount determined by consecutive sampling method.

Results of this study analyzed by t-test. This study commenced in Thalassemia Clinic of Pediatric Department of RSUP Dr. Hasan Sadikin Bandung from August to September 2009. Crown length measurement taken using the Seow and Lai Method, which transferred the outline of the tooth to an acetate tracing paper using a $2 \mathrm{~B}$ pencil at $0.35 \mathrm{~mm}$ in diameter, subsequently drew a line representing the tooth axis from the deepest occlusal pit to the tooth furcation, then the crown 
Table 1. Mean of right lower permanent first molar crown length in beta major thalassemia children and normal children at $11-13$ years old

\begin{tabular}{ccc}
\hline $\begin{array}{c}\text { Age } \\
\text { (year) }\end{array}$ & $\begin{array}{c}\text { Normal } \\
\text { children }(\mathrm{mm})\end{array}$ & $\begin{array}{c}\text { Beta major thalassemia } \\
\text { children }(\mathrm{mm})\end{array}$ \\
\hline 11 & 6.16 & 5.45 \\
12 & 6.07 & 5.72 \\
13 & 6.70 & 5.48 \\
Total & 6.50 & 5.55 \\
\hline
\end{tabular}

length determined in a distance from the deepest occlusal pit to the furcation of the tooth along the axis line. ${ }^{7}$

Root length measured using the similar method with the crown length procedure, which transferred the outline of the tooth into an acetate tracing paper with a $2 \mathrm{~B}$ pencil $0.35 \mathrm{~mm}$ diameter, then the root length determined by measuring the distance from the tooth furcation to the most apical part of the tooth. ${ }^{7}$ Measurement done three times for each tooth, then its average calculated. Data obtained were analyzed with the $t$ test for the two groups. ${ }^{8}$

\section{RESULTS}

The total sample amount of this study was 12 children for each group. Mean of right lower permanent first molar crown length for the betamajor thalassemia children aged $11-13$ years old was $5.55 \mathrm{~mm}$, while in the normal children was 6.50 $\mathrm{mm}$ (Tab.1). Mean of right lower permanent first molar root length for the beta-major thalassemia children aged $11-13$ years old was $7.70 \mathrm{~mm}$, while in the normal children was $8.96 \mathrm{~mm}$ (Tab. 2).

The result of this study showed that there was a difference in right lower permanent first molar crown length of beta-major thalassemia children compare to normal children at 11-13 years old.

The result showed that between children with beta-major thalassemia and normal children at 11-13 years old there was a difference of root length of the right lower permanent first molar significantly, which means that the right lower permanent first molar root length in beta-major thalassemia children lower than the root length in normal children.
Table 2. Mean of right lower permanent first molar root length in beta major thalassemia children and normal children at 11-13 years old

\begin{tabular}{ccc}
\hline $\begin{array}{c}\text { Age } \\
\text { (year) }\end{array}$ & $\begin{array}{c}\text { Normal } \\
\text { children }(\mathrm{mm})\end{array}$ & $\begin{array}{c}\text { Beta major thalassemia } \\
\text { children }(\mathrm{mm})\end{array}$ \\
\hline 11 & 7.67 & 6.85 \\
12 & 9.23 & 8.94 \\
13 & 9.02 & 7.32 \\
Total & 8.96 & 7.70 \\
\hline
\end{tabular}

\section{DISCUSSION}

The fact that crown and root length of right lower permanent first molar in beta-major thalassemia children group are shorter than the normal group, correspond with a study of Davey and Poyton', which suggested that more than $50 \%$ of the sample showed shortened teeth.

Al-Jamal and Hazza'a ${ }^{1}$, suggested that the size (length) differences occured as a result from genetical variation and also the environmental factors, such as somatomedin and endocrinal disorder. Both major factors become a causal factor of several clinical manifestations in betamajor thalassemia children.

Beta-major thalassemia manifestation throughout the body depends on the anemia severity, patient age, and clinical symptoms duration. ${ }^{10}$ According to Margo et $\mathrm{al}^{11}$ these three factors correspond with the blood transfusion dose in beta-major thalassemia children. The high blood transfusion frequency will cause deposits of iron throughout the body tissues. ${ }^{10}$

Results from several studies indicated that overbalanced iron was the main cause of death and complication of disease in beta-major thalassemia patient. Deposition of iron in inner organ (particularly the heart, liver and endocrine) became a causal factor for tissue breakdown and would subsequently lead to disfunction and organ failure. ${ }^{12}$

According to Al-Jamal and Hazza' $\mathrm{a}^{1}$ the endocrinal breakdown in beta-major thalassemia children had a correlation with the dental development. This theory correspond with Behrman and Vaughan ${ }^{13}$, which suggested that sound dental structure helped with diet contained adequate protein, calsium, phosphate, vitamin $\mathrm{C}$ and $\mathrm{D}$, also 
the thyroid hormone. Ratnakusuma ${ }^{14}$ added that parathormone produced by the parathyroid gland affected the bone dynamics and if any insufficiency of this hormone occured in dental developmental ages, then enamel hypoplasia, root malformation and impaired dental development occured.

A number of literature had described a lead regarding the existence of a correlation between the dental and bone development. ${ }^{1}$ This literature based on a theory regarding the similarity of anorganic component inside the bone and dental structures. According to Feldman and Dahlin ${ }^{15}$, $90 \%$ of bone anorganic composition consisted of calcium phosphate and another 10\% in form of calcium carbonate deposited beneath the organic matrix as a hydroxyapatit, while Scheid ${ }^{16}$, suggested that enamel, cementum, and dentin consist from $95 \%$, $65 \%$, and $70 \%$ of calcium hydroxyapatit sequentially. The parathormone plays an important role in calcium metabolism process. ${ }^{14}$ Minimal hormone quantity produced caused by impaired parathyroid glands as suggested by Rund and Rachmilewitz ${ }^{12}$, suspected as a major factor in inhibition of dental growth and development which indeed major structure formation depended on this hormone production activity.

Behrman and Vaughan ${ }^{13}$ added that growth disorder can be related with a chronical disease therefore the need of special precaution regarding conditions affected the development such as nutrition is essential. According to Moyrs ${ }^{17}$, nutrition condition had a strong relationship with social-economical condition.

A source from Sinar Harapan Newspaper ${ }^{18}$, described that most of the beta-major thalassemia are people with low social-economic level. The low social-economic condition cause a limited source of funds available for medication of betamajor thalassemia. This factor affect oftenly to the irregular schedule of blood transfusion and also its affordability to provide food with sufficient nutrition for the patient. This condition exacerbate the clinical symptoms of beta-major thalassemia patient and growth-developmental disturbance continue to occur.

Indeed it was showed that most of the betamajor thalassemia children in Thalassemia Clinic of Pediatric Department, RSUP Dr. Hasan Sadikin Bandung, had a slow growth and development. Their physical appearances were not as their age, therefore it was difficult to determine their ages without directly asking the patient or their family regarding the patient age. The slow growth pattern manifested on their less body weight and height. According to Sjahruddin ${ }^{19}$, body weight and height are one indicator of child growth which depicted their nutritional status.

Several studies mentioned that insufficiency of nutrition mostly happened in beta-major thalassemia patient, such as Vitamin C insufficiency as a result of rapid catabolism and deficiency of Vita$\min \mathrm{E}$ because of haemolysis. Folic acid deficiency occured because of decreased absorption rate, minimum food intake, and more vitamins need because of rapid bone marrow expansion. ${ }^{20-22}$

Adequate blood transfusion, removal of excessive iron, and good nutritional intake can reduce the negative impact of beta-major thalassemia patient, including dental growth and development. ${ }^{10,12}$

\section{CONCLUSION}

The length of crown and root of right lower permanent first molar in beta-major thalassemia children are different from normal children at age of 11-13 years old. The length of crown and root of right lower pemanent first molar in beta-major thalassemia children are shorter than normal children. It needs socialization regarding the issue of length differences in crown and root of the right lower permanent first molar to dentists and dental assistants, it aims in particular they carefully address this issue while doing dental treatment to beta-major thalassemia children.

\section{REFERENCES}

1. Al-Jamal G, Hazza'a AM. Dental development in subjects with thalassemia major. J Contemp Dent Pract 2006;4:2.

2. Kompas. Cyber media. Skrining thalassemia. [cited 2009 May 9]. Available from: http:// www.kompas.com/kompas-cetak. 2002.

3. Kumar V, Robbins SL. Basic pathology, part II. Jakarta: EGC; 1995. p. 5, 11-2.

4. Purba IG. Gambaran radiografi rongga mulut dan wajah pada penderita thalasemia betamayor. J USU Lib 2008.

5. Foster TD. Buku ajar ortodonsi. $3^{\text {rd }}$ ed. Jakarta: 
EGC; 1993. p. 4-5, 7, 12, 49.

6. Berkovitz BKB, Holland GR, Moxham BJ. Oral anatomy, embriology and histology. $3^{\text {rd }}$ ed. Edinburgh: Mosby: 2002;27-8.

7. Seow WK, Lai PY. Association of taurodontizm with hypodontia: A controlled study. J Pediatr Dent 1989;11:214-9.

8. Woolson RF. Statistical methods for the analysis of biomedical data. Canada: John Wiley and Sons Inc.; 1987. p. 156-8,187-91.

9. Davey KV, Poyton. Thalassemia: changes visible in radiographs used in dentistry. $\mathrm{J}$ Oral Surg Oral Med Oral Pathol 1968;25:564,756.

10. Al-Wahadni A Qudeimat MA, Al-Qomari A. Dental arch morphological and dimensional characteristic in Jordanian childrens and young adults with beta thalassemia major. Int J Pediatr Dent 2005:98-102.

11. Magro S. Hypothyroidism in patients with thalassemia syndromes. J Acta Haematol 1990;84:72-6.

12. Rund D, Rachmilewitz E. Medical progress beta-thalassemia. Boston: New Eng J Med 1990;353(11):135.

13. Behrman RE, Vaughan VC. Ilmu kesehatan anak. $12^{\text {th }}$ ed. Jakarta: EGC; 1998. p. 36.

14. Ratnakusuma AB. Metabolik endokrinologi rongga mulut. Jakarta: Universitas Indonesia; 1992.
15. Feldman F, Dahlin DC. Bone diseases macroscopic histological and radiological diagnosis of structural changes in the skeleton. Heidelberg: Springer; 2000. p. 6.

16. Scheid RC. Dental anatomy: Its relevance to dentistry. $7^{\text {th }}$ ed. Philadelphia: Lippincott Williams and Wilkins; 2002. p. 116, 327.

17. Moyers RE. Handbook of orthodontics. $4^{\text {th }}$ ed. Chichago: Year Book Medical Publisher; 1988. p. 14, 18, 20, 22, 28.

18. Sinar Harapan, Cyber Media. Thalassemia dan sosial ekonomi. 2002 [cited 2009 Feb 19]. Available from: http//:www.sinarharapan. co.id/.

19. Sjahruddin LD. Indeks kelainan dentofacial dan maturasi tulang vertebra vertikal pada penderita thalassemia beta hemoglobin $\mathrm{E}$ serta hubungannya dengan beberapa faktor resiko. Dissertation. Jakarta: Universitas Indonesia; 2004. p. 3, 48, 51.

20. Nathan DG, Oski FA. Hematology of infancy and childhood. $4^{\text {th }}$ ed. Vol I. Pensylvania: W.B. Saunders Co.; 1993. p. 39.

21. Miller JL. Blood disease of infancy and childhood. $7^{\text {th }}$ ed. St. Louis: Mosby Year Book Inc.; 1995. p. 2, 12-3, 39.

22. Kosasih. Buku ajar ilmu penyakit dalam. $3^{\text {th }}$ ed. Jakarta: Balai Penerbit Fakultas Kedokteran UI; 2001. p. 39. 